\title{
A Mathematical Approach to Evaluating the Influence of Various Factors on the Stability of Aggregates in Vertisols ${ }^{2}$
}

\author{
M. A. Lugo López and Raúl Pérez Escolar ${ }^{2}$
}

INTRODUCTION

The stability of soil aggregates is one of the most important of the soil properties. It is especially important from the standpoint of air and water movement in particular, and soil conservation in general. Although many attempts have been made to evaluate the factors influencing the stability of soil aggregates, there is as yet no precise scientific information to provide satisfactory explanations. It is generally believed that the stability of soil aggregates depends on a number of other soil properties, such as nature and content of small-sized particles, organic matter, iron oxides and others. In a previous study, Lugo-López and Juárez, Jr. (2) found through simple regression analyses that there was no correlation between aggregate stability and clay or silt content. However, a highly significant correlation was obtained when organic-matter content was considered as the independent variable. In spite of the level of significance only 16 percent of the variability in aggregate stability could be explained on a basis of the soil organic-matter content. This paper reports on a mathematical study designed to explore certain of the several factors which may logically influence stability.

\section{THE SOILS USED IN THIS STUDY}

Data for this work were taken from a comprehensive study of the nature and properties of the major soils of the Lajas Valley, Puerto Rico (3). The study included mostly soils of the lower valley, such as those of the Aguirre, Guánica, San Antón, Santa Isabel, Fraternidad, and Fe series. These major soils of Lajas Valley exhibit certain characteristics in common. They are very deep with a strikingly high, almost uniform, clay content of the expanding-lattice type; predominantly small pores, very slow hydraulic conductivity in the subsoil; very low aggregate stability below the surface

1 Vertisols are mineral soils at least 20 inches deep, with 30 -percent or more clay in each horizon, with cracks in a given period throughout the year at least $1 / 2$ inch wide and 20 inches deep.

2 Soil Scientist and Associate Soil Scientist, respectively, Agricultural Experiment Station, Mayagüez Campus, University of Puerto Rico, Río Piedras, P.R. Appreciation is expressed to Mr. Mariano Antoni, Research Assistant in Statistics, for his valuable cooperation in developing the work herein reported.

Italic numbers in parentheses refer to Literature Cited, p. 60. 
layer; but with a topsoil about 1 foot, in some cases almost 2 feet deep, that conducts water rather well. They are relatively low in organic matter and nitrogen, and generally high in soluble salts and exchangeable sodium, which increases with depth. The soils included in this study are classified as Vertisols. ${ }^{4}$

\section{MATERIALS AND METHODS}

Aggregate stability was determined by the method of Bryant, Bendixen, and Slater (1). Particle-size distribution was determined by the standard pipette method. Organic matter was determined by the chromic acid reduction method. Water-soluble calcium + magnesium was determined by the versenate titration method. Soluble sodium was taken to be the difference between electrical conductivity values $\times 10$ and calcium + magnesium. Specific electrical conductance measurements were made, using saturation extracts, with a standard solubridge.

Analyses of variance were made and coefficients of correlation and determination were calculated by following the least-squares method (4). The correlation coefficient indicates the closeness of the relationship between aggregate stability and the independent variables, i.e., clay, silt, organic matter, $\mathrm{Ca}+\mathrm{Mg}$, and soluble sodium. The coefficient of determination is the ratio of the difference between the squared standard deviation and the squared standard error of estimate to the original variability. It indicates the proportion of the variability in aggregate stability which can be explained on the basis of the independent variables used.

\section{RESULTS AND DISCUSSION}

Data in table 1 show the relationships between the stability of soil aggregates and such other variables as clay content, silt, organic matter, soluble calcium + magnesium, and soluble sodium content. The relationships between aggregate stability and clay, and aggregate stability and silt and clay were not significant. This stresses the role of clay per se as a binding body of soil particles, and not as a stabilizing agent. The percentage of the variability in aggregate stability that could be explained in terms of these two factors is negligible. However, when the content of organic matter was incorporated into the multiple correlation analysis a correlation coefficient of 0.66 was obtained. Thus, on the basis of organic-matter content and, disregarding the negligible portion of the variability which could be attributed to clay and silt, almost 43 percent of the variability in aggregate stability could be explained. When the values for the combined $\mathrm{Ca}+\mathrm{Mg}$ content were introduced into the equation the closeness of the

4 Luis H. Rivera. USDA Soil Conservation Service. Personal communication. Jan. 1968. 
relationship increased, as shown, by a correlation coefficient of 0.70 . When the soluble sodium was also included the correlation coefficient further increased to 0.75 . In the latter two cases, some 49 and 56 percent of the variability in aggregate stability could be explained. The additional variability that could be explained in both cases was statistically significant at the 1-percent level. The increase in correlation coefficient with the inclusion of soluble $\mathrm{Ca}, \mathrm{Mg}$, and $\mathrm{Na}$ indicates that the stabilizing effect of organic matter is improved by the dehydrating action of soluble salts. The presence of high sodium in solution is an important fact in the sense that the dissociation of the exchangeable sodium in equilibrium is repressed. It is well known that this dissociation is what causes deflocculation.

Thus, in the montmorillonitic soils of the Lajas Valley aggregate stability is, in large measure, a function of the organic-matter content of the soil.

TaBLE 1.-Relationships between the stability of soil aggregates and certain other variables 1

\begin{tabular}{l|c|c|c}
\hline \multicolumn{1}{c|}{ Independent variables } & F-value & $\begin{array}{c}\text { Correlation } \\
\text { coefficiont }\end{array}$ & $\begin{array}{c}\text { Coefficient of } \\
\text { determination }\end{array}$ \\
\hline Clay & 0.75 & 0.08 & 0.006 \\
Clay + silt & .80 & .11 & .013 \\
Clay + silt + organic matter & $29.78^{2}$ & .66 & .429 \\
Clay + silt + organic matter + Ca and $\mathrm{Mg}$ & $28.48^{2}$ & .70 & .491 \\
Clay + silt + organic matter + Ca and Mg + Na & $29.31^{2}$ & .74 & .556 \\
\hline
\end{tabular}

1 Statistical studies included 123 values in esch case.

Highly significant.

As previously mentioned, the organic-matter analyses herein used were conducted on whole soils. In all probability, if organic matter had been determined in the particular-sized aggregates used, then the relationship, perhaps would have been closer, and a larger proportion of the variability in aggregate stability could have been explained. The statistical studies herein reported further show that clay is not active as an aggregate stabilizing agent in these types of soils. The silt fraction is not active either in this respect. Water-soluble calcium and magnesium, as well as water-soluble sodium, do contribute somewhat as aggregate stabilizing agents.

\section{SUMMARY}

A mathematical approach is presented in this paper to evaluate the influence of such factors as clay content, silt content, organic matter, $\mathrm{Ca}+$ $\mathrm{Mg}$, and soluble sodium upon the stability of soil aggregates in a group of Vertisols from the Lajas Valley, P.R. The relationships between aggregate stability and silt and clay were not significant. When the percentage of 
organic matter was considered as the independent variable, a highly significant correlation coefficient of 0.66 was obtained. Therefore, almost 43 percent of the variability in aggregate stability could be explained on the basis of this single factor. Attempts to increase the percentage of the variability which could be explained in terms of the content of $\mathrm{Ca}+\mathrm{Mg}$, and also of soluble sodium, yielded correlation coefficients of 0.70 and 0.74 , respectively. Thus, only a slight, but significant, additional increase could be explained when these variables were included.

\section{RESUMEN}

Se presenta en este trabajo una evaluación matemática del efecto de factores tales como el contenido de arcilla, limo, materia orgánica, calcio + magnesio y sodio soluble sobre la estabilidad de los agregados de un grupo de Vertisols del Valle de Lajas, Puerto Rico. Las relaciones entre la estabilidad de los agregados y el contenido de arcilla y limo no fueron significativas. Cuando se incluyó el contenido de materia orgánica como otra variable independiente se obtuvo un coeficiente de correlación de 0.66 que resultó ser altamente significativo. Por lo tanto, se logró explicar casi el 43 porciento de la variabilidad en estabilidad de los agregados a base de esta sola variable. Cuando se trató de explicar una mayor proporción de la variabilidad en términos del contenido de $\mathrm{Ca}+\mathrm{Mg}$ y de sodio soluble se obtuvieron coeficientes de correlación de 0.70 y 0.74 , respectivamente. De manera que, solamente una pequeña, pero significativa, porrión adicional de la variabilidad puede atribuirse a estas variables.

\section{LITERATURE CITED}

1. Bryant, J. C., Bendixen, T. W., and Slater, C. S., Measurements of the water stability of soils, Soil Sci. 66: 345, 1948.

2. Lugo-López, M. A., and Juárez, Jr., J., Evaluation of the effects of organic matter and other soil characteristics upon the aggregate stability of some tropical soils, J. Agr. Univ. P.R. 49 (4): 268-72, 1959.

3. Lugo-López, M. A., Pérez-Escolar, R., Acevedo, G. and Juárez, Jr., J., Nature and Properties of Major Soils of Lajas Valley, Bull. 149, Agr. Expt. Sta., Univ. P.R. 1959.

4. Pearson, F. A., and Bennet, K. R., Statistical Methods, John Wiley \& Sons, Inc., New York, N.Y., 1942. 